\title{
CONCEPTUAL APPROACHES TO ORGANIZING MODEL OF UNIVERSITY STOMATOLOGICAL CLINIC, BASED ON PUBLIC-PRIVATE PARTNERSHIP
}

DOI: 10.36740/WLek202008111

\author{
Vitaliy D. Chopchik, Oleksander A. Kaniura \\ BOGOMOLETS NATIONAL MEDICAL UNIVERSITY STOMATOLOGICAL MEDICAL CENTER, KYIV, UKRAINE
}

\begin{abstract}
The aim: to substantiate conceptual approaches to organizing the model of university stomatological clinic based on the public-private partnership principles (PPP).

Materials and methods: To achieve the aim the author used general scientific methods of analysis, synthesis, generalization, interpreting scientific data as well as systemic and structural-functional approaches. The conceptual approaches comply with the Constitution of Ukraine, laws and other legislative standards of Ukraine, generally accepted standards and principles of world law in the healthcare, considering the Ukrainian and foreign experience.

Results: The article represents conceptual approaches to organizing university clinic, based on the public-private partnership principles, in order to provide development of theoretical and practical stomatology, training professionals as well as to providing accessible and affordable high-quality stomatological service to population.

Introduction of the conceptual approaches will provide for development of a modern model of the university clinic, creating public-private healthcare institution which will provide affordable and high-quality stomatological service corresponding to modern requirements and approaches ( last advances of science and technology). Implementation of the public-private partnership mechanisms will be a guarantee of steady long-lasting social-economic development of the clinic.

Conclusions: The priority way of development of the university clinics under new economic conditions is basing their economic mechanisms on the PPP principles. To realize this, the conceptual approaches to organizing university stomatological clinic model based on the public-private partnership principles were introduced (with the example of university stomatological clinic).
\end{abstract}

KEY WORDS: university medicine, dental care, financing, economic management

Wiad Lek. 2020;73(8):1650-1654

\section{INTRODUCTION}

Analysis of the foreign university clinics experiences evidences that the development of the university clinical institution network is possible only with innovations in fundamental science and introduction of the clinics applying new effective diagnostic and treatment technologies into practice, under the circumstances of private investment $[1,2,3]$. So, this requires for appropriate financial funding. Some postulates should be mentioned:

- no country in the world is able to maintain clinics and provide population with high-quality modern medical (including the stomatological) service only by state budget financing;

- no country in the world is able to maintain medical buildings, purchase new technologies and medical materials only by state budget financing. This is why medical institutions are looking for additional budget sources to provide their functioning;

- there is no free stomatological service in the world. So the issue of stomatological service should always be considered referring to the budgeting sources and their characteristics;

- re-equipping medical institutions budgeted by state is impossible, as nowadays state financing only by $30 \%$ provides certain issues of state stomatological institutions service;
- it is impossible to solve problems of health service and stomatological service without engagement of several financing sources, without regarding social factors and without constructive interaction of the state with private investors.

An important issue of stomatological service management is absence of agreement of the state and stomatologists on the following:

The state cannot provide:

- affordability and availability of stomatological service for all population groups;

- quality of stomatological service;

- social and economic acceptability ( both for the state and population) of stomatological service;

- effective financing of stomatological service which will be free for population $[4,5,6]$;

Population cannot obtain:

- available and affordable high-quality stomatological service;

- social and economic acceptability and attraction of stomatological service $[7,8,9]$.

Stomatologists aren't provided with:

- decent salary;

- professional and social guarantees;

- professional, functional and resource support of their 


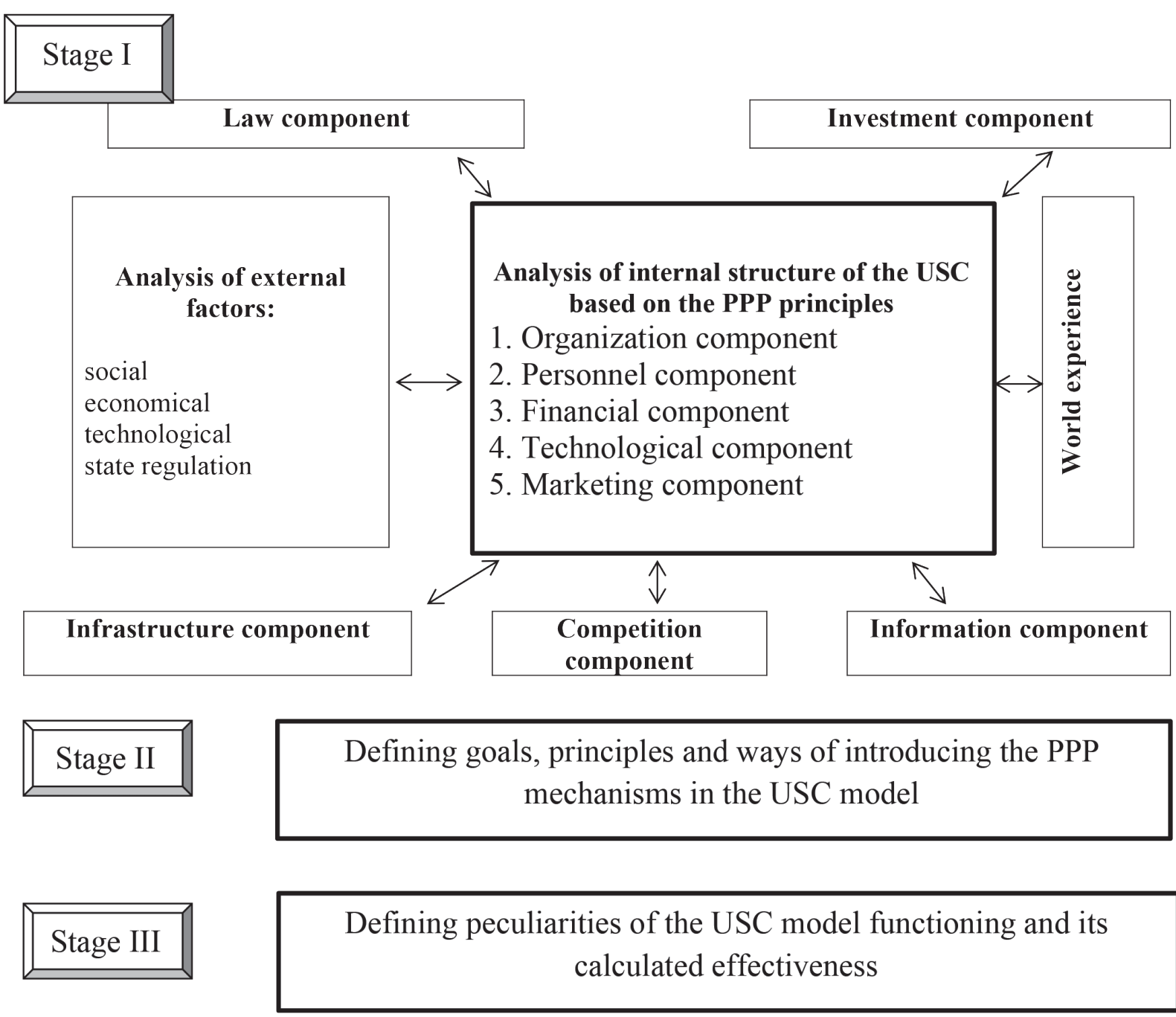

Fig. 1. Concept approach to the gradual organization of the USC model based on the PPP principles (own development of authors)

work, availability of continuous knowledge and technologies reformation $[4,5]$.

It is possible to correct the recalled above drawbacks only with implementing public-private partnership system (PPP) as a combination of long-lasting interaction of state and business aimed at solving the recalled socially significant tasks, which will be mutually beneficial.

Strategic partnership of state and business may become the priority method of successful university clinics development [10-15].

\section{THE AIM}

The objective of this study was to substantiate conceptual approaches to organizing the model of university stomatological clinic based on the public-private partnership principles.

\section{MATERIALS AND METHODS}

To achieve the aim the following methods were used: general scientific analysis, synthesis, generalization, scientific data interpreting as well as systemic and structural-functional approaches.

The conceptual approaches were prepared according to the Constitution of Ukraine, generally accepted principles and standards of international law within the healthcare, regarding the Ukrainian and foreign experience.

\section{RESULTS}

Foreign experience evidences that application of the public-private partnership mechanisms in healthcare provides for optimizing state budget charges; providing competitive ability of the healthcare institutions and managing private medical service market, with its development regarding real requirements of certain regions; investing additional resources into reconstruction of the existing healthcare objects; creating new clinics network and implementing there new medical technologies, improving quality and accessibility of medical service for population as well as improving the service quality $[2,3,5]$. 
The development of conceptual approaches to the university stomatological clinic (USC) model based on the public-private partnership provides for realizing the public-private partnership (PPP) mechanisms in the university stomatological clinics.

It is necessary to note that organization and further development of the USC based on the PPP principles is implemented in stages (Fig. 1).

The first stage of the concept USC organization, based on the PPP principles, includes strategy analysis. There should be analyzed complex of the internal and external factors which may affect the PPP in healthcare. It is necessary to study functioning conditions of the PPP system, regarding the advanced foreign experience, coordinate common activity of private sector and state authorities, and the basis for the PPP project is formed.

Due to the conducted strategy analysis it is necessary to assess the internal and external factors effect on the PPP within the university clinic model.

The second stage includes defining universal components of the PPP: aims, principles and ways of the PPP implementation according to the tasks of the PPP project.

The basic universal elements of the PPP organization are as follows:

- defining the PPP aims: economically efficient solution of the significant state sector task: organizing university stomatological clinic on the PPP arrangement principles, providing socially valuable service;

- defining the PPP relations participants: state and private structures;

- securing the average- or long-duration relations of the PPP arrangement participants by official documentation ( agreement, standard law act, etc.);

- planning common implementation of the investment project by public and private partners;

- distribution of competencies, risks, revenues and expenses between the PPP sides.

The main aim and tasks of the state-private partnership organization.

\section{For the state authorities:}

Aims: - minimizing budget charges providing economic and social state functions. Reinforcement of the budget and increasing tax revenues.

Tasks: - increasing the added value and improving quality of service.

\section{For the private structures:}

Aims: - maximizing profit from common with public sector business project;

Tasks:

- reinforcement of market position, diversification;

- increasing the competitive ability;

- diligent performance of obligations;

- justified distribution of risks and liabilities;

- development of production and social infrastructure, predisposing for increasing the benefit.

The basic principles of the public-private partnership are: On behalf of the state partners:

Target purpose, legal order, consistence, social-economic effectiveness of the budget funding application, mutual benefit, information and activity transparency, equal rights of the partners.

\section{On behalf of the private structures:}

- targeting, party responsibility, investment prospects, socially-centered activities, continuous actualization, competitive ability.

According to all the above mentioned, it is possible to conclude that the PPP universal components are complementary for the PPP parties.

The third stage includes defining peculiarities of organization and improvement of theoretical and practical USC functioning model, calculated efficiency of introducing the PPP technologies into the USC, perspectives of upgrading the curative, scientific and training directions as well as the dynamic effect of the project onto the development of stomatological service economic component.

It is necessary to note that organization and further implementation of the PPP mechanisms into the USC is characterized by certain peculiarities, which may affect interaction between the state and private partners.

First of all, the PPP is a basic, most common mechanism of liberal market economics, which provides for fulfilling the potential of advanced relations between the public(state) sector and private business.

Secondly, partnership of state and business provides for increasing investments to the USC, which functions based on the PPP principles.

Thirdly, it allows using the private initiative and advanced experience to create economically steady USC based on the PPP principles. Private business, compared to state structures, is characterized by higher resource mobility and flexibility, quicker decision-making process, being more adapted to changes of functioning; better ability of implementing innovations, being directed to introduce new methods and implement new technical and technological advances, in order to provide for the USC competitive ability.

The fourth is that the resources and efforts of the state authorities within the certain USC project based on the PPP principles create additional competitive economic benefits. This happens due to creation of the steady legislative background, favorable political climate, and implementation of the organization structural measures, support and guarantees in interaction with the civil society, use of financial and economic instruments: subventions, guarantees, privilege tax liability and other types of support.

All this affects the investment attractiveness of the USC based on the PPP principles and provides for optimizing training and science development, improvement of the university clinical background in order to provide the high-quality, affordable stomatological service to all population layers.

\section{DISCUSSION}

The developed conceptual approaches will contribute to solving the following problems:

- improving organization of stomatological service rendered to population, increasing its affordability, quality 
and efficiency, increasing the economic autonomy of the USP, higher responsibility for economic outcomes;

- development of stomatology and introducing innovations, optimizing legislative and economic relations in the USC between stomatological scientific, training and curative-preventive clusters within common clinical university clinics;

- development of training management. Providing informational support of students and stomatologists: creating electronic libraries and information databases, implementation of information technologies and systems of quality management into the training process;

- creating effective model of managing the financial resources;

- effective planning of the personnel, financial and other material and non-material resources, necessary for providing stomatological service of appropriate quality; - informational support of the USC;

- providing legislative and financial conditions to develop the system which will maintain effective medical personnel functions;

- increasing accessibility and quality of specialized, including the high-technology stomatological service;

- implementing standards of management of patients with various stomatological pathologies;

- specifying guarantees of free stomatological service provided by the USC to certain population groups;

- equipping the USC with modern medical diagnostic equipment;

- hiring high-professional medical staff;

- providing necessary drugs and other medical issues;

- organizing the system of target values and improving the policy which will assess not only kinds and volume of the stomatological service, but its quality;

- increasing the professional level of medical personnel, basing on the continuous postgraduate education and training specialists- managers of healthcare;

- preparing programs of international exchange within the professional actualization of stomatologists; cross-exchange residency of students in leading clinics of the world as well as of the foreign students in the USC.

The presented results of the work are original and are potential methodological materials for the development of any model of university clinic based on the public-private partnership principles.

\section{CONCLUSIONS}

Conducted study allowed to develop conceptual approaches to the formation of the USK model on the principles of PPP, aimed at providing affordable and high-quality dental care.

The formation of the economic mechanism of the USK model on the principles of PPP is a priority for the development of the clinical bases of universities in the new economic conditions.

The represented conceptual approaches should be regarded as methods of assessing opportunities and prospective of the public-private business union development, as a set of the most common methods and solutions of a complex practical task - organizing the university stomatological clinic model, based on the PPP principles.

The prospective further studies should be regarded as application of the obtained results for reasoning and organizing model of university stomatological clinic, based on the public-private partnership principles.

\section{REFERENCES}

1. Rees P. J., Stephenson A. E. The future of medical education in the UK. Br J Gen Pract. 2010; 60(580): 795-796.

2. Oganezova A. V. Uníversitets'ka klíníka yak ínnovatsíyna forma rozvitku okhoroni zdorov'ya [University Clinic as an innovative form of health care development]. Business Inform. 2017; 11: 146-152. (In Ukrainian).

3. Torchia M., Calabria A., Morner M.Public-private partnerships in the health care sector: A systematic review of the literature. Public Manag. Rev. 2015; 17 (2): 236-261.

4. Pavlenko 0.V., Vakhnenko 0.M. Shlyakhy reformuvannya systemy nadannya stomatolohichnoyi dopomohy naselennyu Ukrayiny. Dyskusiya [Ways of reforming the system of rendering dental care to the population of Ukraine. Discussion]. Modern dentistry. 2013;4:180-184. (In Ukrainian).

5. Kosenko K.N., Reyzvykh 0.É. Sostoyanye stomatolohycheskoy pomoshchy v Ukrayne [The state of dental care in Ukraine]. Economics and Management in Dentistry. 2012; 2 (37): 57-61. (In Russion).

6. Stomatolohichna dopomoha v Ukrayini /osnovni pokaznyky diyal'nosti za 2008-2018 roky/ Pid redaktsiyeyu Voronenka YU.V., Pavlenka 0.V., Mazur I.P. [Dental care in Ukraine / main performance indicators for 2008-2018]. Polium; 2018, 215 p. (In Ukrainian).

7. Dychko E.N., Kovach I.V., Khotims'ka Y.V. et al. Chastota stomatolohichnykh zakhvoryuvan' u ditey [Frequency of dental diseases in children]. Medical perspectives. 2012; 7 (2):114-116. (In Ukrainian).

8. Klymenko V.I., Smirnova I. V. Stan stomatolohichnoho zdorov ya naselennya zalezhno vid sotsial'noho statusu ta zadovolenosti medychnoyu dopomohoyu [Dental health status of the population depending on social status and satisfaction with medical care]. Wiadomosci Lekarskie. 2014; 67 (2): 199-201. (In Ukrainian).

9. Klymenko V.I., Smirnova I. V. Obgruntuvannya funktsional'noyi modeli profilaktyky poshyrenosti ta intensyvnosti poshyrenykh stomatolohichnykh zakhvoryuvan' [Substantiation of functional model of prevention of prevalence and intensity of widespread dental diseases]. Ukraine. The nation's health. 2015; 2: 68-75. (In Ukrainian)

10. Alonso J. M., Clifton J., -Fuentes D. Díaz Public private partnerships for hospitals. Does privatization affect employment? J. Strateg. Contract. Negot. 2016; 2 (4): 313-325.

11. Cappellaro G., Ricci A.PPPs in health and social services: a performance measurement perspective. Public Money Manage. 2017;37 (6): 417-424.

12. Durand M., Petticrew M., Goulding L. An evaluation of the Public Health Responsibility Deal: Informants experiences and views of the development, implementation and achievements of a pledge-based, public-private partnership to improve population health in England. Health Policy. 2015; 119 (11): 1506-1514.

13. Medhekar A. Public-private partnerships for inclusive development: Role of private corporate sector in provision of healthcare services. Procedia Soc. Behav. Sci. 2014; 157.: 33-44.

14. Roehrich J. K., Lewis M. A., George G.Are public-private partnerships a healthy option? A systematic literature review. Soc. Sci. Med. 2014; 113: $110-119$. 
15. Sadeghi A., Barati 0., Bastani P. et al. Experiences of selected countries in the use of public-private partnership in hospital services provision. J. Pak. Med. Assoc. 2016; 66 (11): 1401-1406.

The research described in this paper was performed according to scientific plan of the Department of Social Medicine and Public Health "Scientific substantiation of staffing of the public health service" (state registration number 0117U002681).

\section{ORCID and contributionship:}

Vitaliy D. Chopchik: 0000-0002-5581-0372 A,B,D,E

Oleksandr A. Kaniura: 0000-0002-6926-6283 A,F

\section{Conflicts of interest:}

Authors declare no conflict of interest.

\section{CORRESPONDING AUTHOR}

\section{Vitaliy D. Chopchyk}

Bogomolets National medical University

1 Zoolohichna, 02000 Kyiv, Ukraine

tel: +380673833423

e-mail: vitalchop@gmail.com

Received: 17.03 .2020

Accepted: 04.06 .2020

A - Work concept and design, B - Data collection and analysis, C - Responsibility for statistical analysis,

D-Writing the article, $\mathbf{E}$-Critical review, $\mathbf{F}$ - Final approval of the article 